\title{
Reelin Expression in Creutzfeldt-Jakob Disease and Experimental Models of Transmissible Spongiform Encephalopathies
}

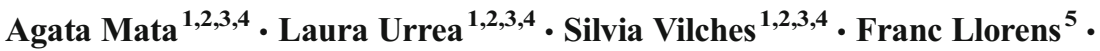 \\ Katrin Thüne $^{5}$ - Juan-Carlos Espinosa ${ }^{6}$ • Olivier Andréoletti ${ }^{7}$. \\ Alejandro M. Sevillano ${ }^{8,9}$ • Juan María Torres ${ }^{6}$ - Jesús Rodríguez Requena ${ }^{8,9}$ • \\ Inga Zerr ${ }^{5}$ • Isidro Ferrer ${ }^{10,11,12}$ • Rosalina Gavín ${ }^{1,2,3,4}$ • José Antonio del Río ${ }^{1,2,3,4}$
}

Received: 11 July 2016/Accepted: 28 September 2016

(C) Springer Science+Business Media New York 2016

\begin{abstract}
Reelin is an extracellular glycoprotein involved in key cellular processes in developing and adult nervous system, including regulation of neuronal migration, synapse formation, and plasticity. Most of these roles are mediated by the intracellular phosphorylation of disabled1 (Dab1), an intracellular adaptor molecule, in turn mediated by binding Reelin to its receptors. Altered expression and glycosylation patterns of Reelin in cerebrospinal and cortical extracts have been reported in Alzheimer's disease. However, putative changes in Reelin are not described in natural prionopathies or experimental models of prion infection or toxicity. With this is mind, in the present study, we determined that Reelin protein and mRNA levels in-
\end{abstract}

Agata Mata and Laura Urrea contributed equally to this study.

Electronic supplementary material The online version of this article (doi:10.1007/s12035-016-0177-8) contains supplementary material, which is available to authorized users.

José Antonio del Río

jadelrio@ibecbarcelona.eu; jadelrio@ub.edu

1 Molecular and Cellular Neurobiotechnology, Institute of Bioengineering of Catalonia (IBEC), Parc Científic de Barcelona, Baldiri Reixac 15-21, 08028 Barcelona, Spain

2 Department of Cell Biology, Physiology and Immunology, Universitat de Barcelona, Barcelona, Spain

3 Centro de Investigación Biomédica en Red sobre Enfermedades Neurodegenerativas (CIBERNED), Barcelona, Spain

4 Institute of Neuroscience, University of Barcelona, Barcelona, Spain

5 Department of Neurology, German Center for Neurodegenerative Diseases - DZNE, Universitätsmedizin Göttingen, Bonn, Germany creased in CJD human samples and in mouse models of human prion disease in contrast to murine models of prion infection. However, changes in Reelin expression appeared only at late terminal stages of the disease, which prevent their use as an efficient diagnostic biomarker. In addition, increased Reelin in CJD and in in vitro models does not correlate with Dab1 phosphorylation, indicating failure in its intracellular signaling. Overall, these findings widen our understanding of the putative changes of Reelin in neurodegeneration.

Keywords Reelin · Creutzfeldt-Jakob disease · Dab-1 . Cellular prion protein
6 Centro de Investigación en Sanidad Animal (CISA-INIA), Madrid, Valdeolmos, Spain

7 UMR INRA ENVT 1225, Interactions Hôtes Agents Pathogènes, Ecole Nationale Vétérinaire de Toulouse, 23 Chemin des Capelles, 31076 Toulouse, France

8 CIMUS Biomedical Research Institute, University of Santiago de Compostela-IDIS, 15782 Santiago de Compostela, Spain

9 Department of Medicine, University of Santiago de Compostela, 15782 Santiago de Compostela, Spain

10 Institut de Neuropatologia, IDIBELL-Hospital Universitari de Bellvitge, Hospitalet de Llobregat, Barcelona, Spain

11 Centro de Investigación Biomédica en Red de Enfermedades Neurodegenerativas (CIBERNED), Barcelona, Spain

12 Institute of Neuroscience, University of Barcelona, Barcelona, Spain 


\section{Introduction}

Reelin is an extracellular matrix protein essential for proper neuronal migration in laminated areas of the developing brain $[1,2]$. In adulthood, Reelin has been localized in synaptic terminals (especially from GABAergic interneurons) and implicated in neuronal plasticity [3, 4]. In fact, Reelin actively participates as a key actor in several neural processes such us cell survival [5] and synaptic plasticity [6-8] as well as in pathological conditions such as ischemia $[9,10]$ and neurodegeneration [11-13]. These results point to the maintenance of Reelin protein levels as crucial for correct homeostatic balance in developing and adult nervous system. In neural tissue, Reelin binds to Apolipoprotein E receptor 2 (ApoER2) and Very Low-Density Lipoprotein Receptor (VLDLR), triggering tyrosine phosphorylation of disabled-1 (Dab1), a cytoplasmic adaptor protein, by kinases of the Src family [14-17]. Following phosphorylation, Dab1 protein recruits the $p 85 \alpha$ subunit of phosphatidylinositol-3 kinase (PI3K), stimulating AKT-phosphorylation, glycogen synthase kinase $3 \beta$ (GSK3 $\beta$ ), and CrkL $[18,19]$.

Reelin protein levels in the brain could be modified by several factors such as hormones [20-24], oxidative stress [25], perinatal stress [26], and exercise [27]. Some of these conditions (e.g., hormone misbalance and oxidative stress) are common features in diseases such as schizophrenia [28, 29] and autism [30], as well as neurodegenerative diseases such as Alzheimer's disease [31, 32] and prionopathies [33]. Indeed, Reelin protein levels are altered in schizophrenia [34] and autism [35] as well as in Alzheimer's disease [36-38]. However, very few data have been reported concerning Creutzfeldt-Jakob disease (CJD) or related models of infective transmissible spongiform encephalopathies (TSEs).

Decreased Reelin levels has been reported in aging [39, 40], mild cognitive dementia, and Alzheimer's disease [36, 41, 42]. Although a low number of Reelin-positive cells have been reported in aged brains, the Reelin decrease in Alzheimer's disease is likely associated with their presence in senile plaques enriched in aggregated $\beta$-amyloid [24, 43, 44]. In fact, it has been suggested that histologically [39] and biochemically [12], Reelin binds to oligomeric $\beta$ amyloid preventing its accumulation in senile plaques. This is in contrast to other studies indicating increased levels of Reelin in late stages (Braak stages III-VI) of Alzheimer's disease [38]. Nonetheless, current studies suggest that reduced levels of Reelin in Alzheimer's disease increases the amyloid burden observed in the disease [7, $12,45]$. In addition, a recent study reports that Reelin produced in the presence of aggregated $\beta$-amyloid showed altered glycosylation [46] and therefore was a nonfunctional protein [11]. Thus, the combination of low protein levels and non-functional Reelin may constitute a vicious circle that promotes the progression of the cognitive impairment in Alzheimer's disease by diminishing synaptic function [13, 47] and cytoskeletal stability [11].

As indicated above, very few data on Reln mRNA or protein levels are reported in Creutzfeldt-Jakob disease or infective prionopathies. In fact, only a recent study analyzing changes in mRNA expression by microarrays in RMLinfected cerebellar organotypic cultures indicated a slight decrease in Reln mRNA at late stages (38 and 45 days) postinfection [48]. This decrease seemed likely to be associated with the relevant granule cell death triggered by the RML infection. In a previous study [49], we determined that mimetic peptides in aggregated form of the human sequence of the cellular prion protein $\left(\operatorname{PrP}_{106-126}\right)$ were able to increase the phosphorylation of Dab1. In parallel, our studies also pointed to an increase in Dab1 phosphorylation and degradation in CJD patients, especially in those with prion type I and Met/ Met 129 polymorphism [50]. Thus, high levels of p-Dab1 leading to low levels of Dab1 rely on low numbers of $\beta$ amyloid plaques [50].

Taking this into account and as natural follow-up to our previous studies, we aimed to explore in the present study the putative changes of Reelin levels in prionopathies employing cytotoxicity models using primary neuronal cultures, prion-inoculated mice, and human sporadic CJD postmortem samples. Results demonstrate that neurons incubated with mimetic prion peptides increased Reelin expression likely by reactive oxygen species (ROS) production. In addition, Reelin and Reln mRNA are increased in post-mortem samples of CJD patients as well as in CJD-infected Tg340 mice in contrast to mice infected with mouse prions.

\section{Materials and Methods}

\section{Mouse Strains and Genotyping}

Adult male C57B16/129sv-Prnp ${ }^{0 / 0}$ (B6129 Prnp ${ }^{\text {Zrchl/Zrchl }}$ Zurich I) mice were purchased from the European Mouse Mutant Archive (EMMA, Monterotondo, Italy) [51]. We backcrossed to $\mathrm{C} 57 \mathrm{BL} / 6 \mathrm{~J}$ for at least 8 generations to obtain 6-7 \% of 129 microsatellites B6.129 Prnp ${ }^{0 / 0}$ and control littermates B6.129 Prnp $^{+++}$. Specific primers to Prnp genotyping were designed in our laboratory based on the original P3 and P10 primers as described [51]: neo: 5'gccttctatcgccttcttgac-3'; 3' NCnew: 5'-gctacaggtggataacccetc$3^{\prime}$ and P10new: $5^{\prime}$-cataatcagtggaacaagccc- $3^{\prime} .40$ cycling condition were $45^{\prime \prime} 95^{\circ} \mathrm{C} ; 45^{\prime \prime} 62^{\circ} \mathrm{C} ; 1^{\prime} 72^{\circ} \mathrm{C}$, followed by a final extension at $72{ }^{\circ} \mathrm{C}$ for $5 \mathrm{~min}$. Prnp-overexpressing mice (Tga20) were purchased from EMMA (Monterotondo, Italy). They were generated as described by Marek et al. [52] and backcrossed in our lab with B6.129 Prnp $^{0 / 0}$ mice for 7 generations. For Tga20 mice, the transgene was detected using primers specific to the Tg20 allele 
5'-caaccgacgtgaagcattctgccta-3' and 5'-cctgggactccttctg gtaccgggtgacgc-3' as indicated [53]. All experiments were performed under the guidelines and protocols of the Ethical Committee for Animal Experimentation (CEEA) of the University of Barcelona, and the protocol for the use of animals in this study was reviewed and approved by the CEEA of the University of Barcelona (CEEA approval no. 276/16 and 141/15).

\section{Mice Inoculated with Different Prion Strains}

As model of mouse prion diseases, we used B6.129 Prnp $^{+/+}$or C57BL/6J intracranially inoculated with two different mouse-adapted prion strains (22L, Mo$\mathrm{BSE}$ ) or with GPI-anchorless $\mathrm{PrP}^{\mathrm{SC}}$ as previously described [54, 55]. As mouse model of sCJD, we used the $\operatorname{Tg} 340$ mouse line inoculated with SCJD prions [56]. Tg340 mice were intracranially inoculated with an sCJD isolate obtained from the UK CJD reference center in Edinburgh [55]. Briefly, 6- to 10-week-old female mice were anesthetized and inoculated with $2 \mathrm{mg}$ of brain equivalent $(20 \mu \mathrm{l}$ of a $10 \%$ brain homogenate) in the right parietal lobe using a 25-gauge disposable hypodermic needle. The mice were observed daily and their neurological status was assessed weekly. When clinically progressive TSE disease was evident, the animals were killed and their brains collected. Brains from those animals were dissected and separated brain zones were frozen at $-80{ }^{\circ} \mathrm{C}$. Mouse inoculation experiments were carried out in strict accordance with the recommendations in the guidelines of the Code for Methods and Welfare Considerations in Behavioral Research with Animals (Directive 86/609EC), and all efforts were made to minimize suffering. Experiments were approved by the Committee on the Ethics of Animal Experiments of the author's institutions (INIA and INRA; and University of Santiago de Compostela, 15005AE/12/FUN01/PAT05/JRR3).

\section{Human CJD Cases}

The brains of 26 patients with sporadic CJD were obtained from 3 to $8 \mathrm{~h}$ after death and immediately prepared for morphological and biochemical studies. The main clinical and pathological characteristics are summarized in Table 1. For biochemical studies, samples of the frontal cortex were frozen in liquid nitrogen and stored at $-80{ }^{\circ} \mathrm{C}$ until use. The standard neuropathological study was carried out on de-waxed 4- $\mu \mathrm{m}$ thick paraffin sections of several brain regions (see [50] for description).
Table 1 Main clinical characteristics of SCJD and control cases in the western blot study

\begin{tabular}{|c|c|c|c|c|}
\hline Case number & Gender & Age & Codon 129 & PrP type \\
\hline CJD1 & $M$ & 25 & $\mathrm{MM}$ & 1 \\
\hline CJD2 & $M$ & 79 & MM & 1 \\
\hline CJD3 & $F$ & 82 & MM & 1 \\
\hline CJD4 & $F$ & 63 & VV & 1 \\
\hline CJD5 & $F$ & 54 & $\mathrm{MM}$ & 1 \\
\hline CJD6 & $F$ & 65 & MM & 1 \\
\hline CJD7 & $M$ & 52 & $\mathrm{MM}$ & 1 \\
\hline CJD8 & $M$ & 61 & $\mathrm{MM}$ & 1 \\
\hline CJD9 & $F$ & 60 & $\mathrm{MM}$ & 1 \\
\hline CJD10 & $M$ & 56 & MM & 1 \\
\hline CJD11 & $M$ & 74 & MM & 1 \\
\hline CJD12 & $F$ & 87 & MV & 1 \\
\hline CJD13 & $F$ & 85 & MM & 1 \\
\hline CJD14 & $F$ & 70 & MM & 1 \\
\hline CJD15 & $F$ & 64 & MM & 1 \\
\hline CJD16 & $M$ & 55 & VV & 1 \\
\hline CJD17 & $M$ & 73 & MM & 2 \\
\hline CJD18 & $F$ & 67 & MM & 2 \\
\hline CJD19 & $F$ & 63 & MM & 2 \\
\hline CJD20 & $F$ & 76 & VV & 2 \\
\hline CJD21 & $F$ & 52 & VV & 2 \\
\hline CJD22 & $M$ & 76 & VV & 2 \\
\hline CJD23 & $M$ & 71 & VV & 2 \\
\hline CJD24 & $M$ & 66 & VV & 2 \\
\hline CJD25 & $F$ & 70 & MV & 2 \\
\hline CJD26 & $M$ & 77 & $\mathrm{MM}$ & 2 \\
\hline Control1 & $M$ & 53 & & \\
\hline Control2 & $M$ & 43 & & \\
\hline Control3 & $M$ & 59 & & \\
\hline Control4 & $M$ & 56 & & \\
\hline Control5 & $M$ & 43 & & \\
\hline Control6 & $M$ & 47 & & \\
\hline Control7 & $M$ & 56 & & \\
\hline Control8 & $F$ & 65 & & \\
\hline Control9 & $F$ & 66 & & \\
\hline Control10 & $F$ & 69 & & \\
\hline
\end{tabular}

$F$ female, $M$ male, $M M$ methionine, $V$ valine, $\operatorname{Pr} P^{s c}$ type 1 lower band of glycosylated $\operatorname{PrP}^{\mathrm{sc}}$ of $21 \mathrm{kD}$, type 2 lower band of glycosylated $\operatorname{PrP}^{\mathrm{sc}}$ of $10 \mathrm{kD}$

\section{Primary Embryonic Neuronal Cultures}

E15.5-16.5 mouse embryo brains were dissected and washed in ice-cold $0.1 \mathrm{M}$ PBS containing $6.5 \mathrm{mg} / \mathrm{ml}$ glucose. The meninges were removed and the cortices isolated. Tissue pieces were trypsinized for $15 \mathrm{~min}$ at $37^{\circ} \mathrm{C}$. After the addition of horse serum and centrifugation, the cells were dissociated by trituration in $0.1 \mathrm{M}$ PBS containing $0.025 \%$ DNAse with a 
polished pipette. Dissociated cells were plated at $\sim 3000$ cells/ $\mathrm{mm}^{2}$ on plates (Nunc, Denmark) coated with poly-D-lysine (Sigma, UK). The culture medium was Neurobasal supplemented with $2 \mathrm{mM}$ glutamine, $6.5 \mathrm{mg} / \mathrm{ml}$ of glucose, antibiotics, and B27 (Invitrogen-Life Technologies, Belgium). After $72 \mathrm{~h}$, AraC $5 \mu \mathrm{M}$ (cytosine $\beta$-D-arabinofuranoside hydrochloride, C6645-100MG, Sigma) was added for $48 \mathrm{~h}$ to inhibit the growth of dividing non-neuronal cells. Cultures contained up to $95 \%$ neurons (TUJ-1+) and were used after 15 days in vitro.

\section{$\operatorname{PrP}_{(106-126)}$ Peptide Treatments}

Prion protein fragments 106-126 (human) and scrambled prion peptide were from Sigma. Peptides $(1 \mu \mathrm{g} /$ $\mu \mathrm{l})$ were dissolved in PBS $0.1 \mathrm{M}$ and allowed to spontaneously aggregate at room temperature for $5 \mathrm{~h}$ and checked at electron microscopy. After aggregation, $\operatorname{PrP}_{(106-126)}$ or scrambled peptides were added to the cortical cultures, which were incubated over a range of times from $30 \mathrm{~min}$ to 4 days. Afterward, the culture medium was collected at $4{ }^{\circ} \mathrm{C}$ and peptide-treated cells were scraped in homogenization buffer containing $150 \mathrm{mM} \mathrm{NaCl}, 1 \mathrm{mM}$ EDTA, $10 \%$ glycerol, $1 \%$ Triton X-100, protease inhibitor cocktail (Roche Farma), and phosphatase inhibitors (10 $\mathrm{mM}$ tetrasodium pyrophosphate $200 \mu \mathrm{M}$ sodium orthovanadate, and $10 \mathrm{mM}$ sodium fluoride). NADPH oxidase-inhibitor DPI (diphenyleneiodonium chloride) $(10 \mu \mathrm{M})$ and $N$ acetyl-L-cysteine (NAC) $(20 \mathrm{mM})$ were from Sigma.

\section{Determination of Cell Death}

Cell death was assessed using a propidium iodide (PI, Sigma-Aldrich) [57]. Briefly, shortly after treatments in 24-well plates, $30 \mu \mathrm{M}$ PI was added to each well. PI fluorescence was measured using a FL600 Microplate Fluorescence Reader (BioTeck). Spectrofluorometer analysis and settings were as follows: 530-nm excitation, 645$\mathrm{nm}$ emission, and data were recorded in relative fluorescence units. As an index of cell death that was not related to actual differences between samples, baseline fluorescence $F_{1}$ was measured $1 \mathrm{~h}$ after addition of PI. Subsequent fluorescence readings were taken at several time points $\left(F_{n}\right)$ after the onset of the experiment, keeping the cells in the incubator between measurements. Finally, the cells were permeabilized for $10 \mathrm{~min}$ at $37{ }^{\circ} \mathrm{C}$ with $500-\mu \mathrm{M}$ digitonin (Sigma Aldrich) to obtain the maximum fluorescence ( $100 \%$ of cell death or $F_{\max }$ ). The percentage of cell death $(\% \mathrm{CD})$ was calculated as follows: $\% \mathrm{CD}=100 \times\left(F_{n}-\mathrm{F}_{1}\right) /\left(F_{\max }-\mathrm{F}_{1}\right)$ [57].

\section{Western Immunoblot}

Samples from different sources were processed for western blot, including human post-mortem samples, mice cortical extract, and cultured cells. The collected samples were homogenized in $(10 \% w / v)$ of $50 \mathrm{mM}$ Tris- $\mathrm{HCl}, \mathrm{pH} 7.4 /$ $150 \mathrm{mM} \mathrm{NaCl} / 0.5 \%$ Triton X-100/0.5 \% Nonidet P-40 and a mixture of protease inhibitor cocktail (Roche) and phosphatase inhibitors ( $10 \mathrm{mM}$ tetrasodium pyrophosphate, $200 \mu \mathrm{M}$ sodium orthovanadate, and $10 \mathrm{mM}$ sodium fluoride). After this, the samples were centrifuged at $15,000 \times \mathrm{g}$ for $20 \mathrm{~min}$ at $4{ }^{\circ} \mathrm{C}$. The resulting supernatant was normalized for protein content using BCA kit (Pierce). Cell extracts were boiled at $96{ }^{\circ} \mathrm{C}$ for $3 \mathrm{~min}$, followed by $6 \%$ SDS electrophoresis, and electro-transferred to nitrocellulose membranes for $2 \mathrm{~h}$ at $4{ }^{\circ} \mathrm{C}$. Membranes were then blocked with $5 \%$ non-fat milk in $0.1 \mathrm{M}$ Tris-buffered saline (pH 7.4) for $2 \mathrm{~h}$ and incubated overnight in $0.5 \%$ blocking solution containing primary antibodies. After incubation with peroxidase-tagged secondary antibodies (1:2000 diluted), the membranes were revealed by ECL-plus chemiluminescence western blot kit (Amershan-Pharmacia Biotech). In our experiments, each nitrocellulose membrane was used to detect reelin (4G10, Millipore), ApoER2 (Milipore), VLDL (MIllipore), $\beta$-actin (1:10,000; Sigma), or tubulin (1:5000; Sigma) $\operatorname{PrP}^{\mathrm{C}}$ levels. For Dab1 immunoprecipitation, $1000 \mu \mathrm{g}$ of total protein was incubated with $\alpha \mathrm{Dab} 1$ (Exalpha Biologicals, Watertown, MA, USA) at $4 \mu \mathrm{g}$ in $500-\mu$ lotal volume overnight at $4{ }^{\circ} \mathrm{C}$. Afterward, immune complexes were precipitated using Protein-G-Sepharose (Amersham-Pharmacia Biotech; Barcelona, Spain) at $4{ }^{\circ} \mathrm{C}$ for $90 \mathrm{~min}$. After centrifugation, proteins were eluted in twice-concentrated Laemmli sample buffer at $96{ }^{\circ} \mathrm{C}$ for $5 \mathrm{~min}$, followed by $10 \%$ SDS-PAGE and immunoblotting using the anti-phosphotyrosine 4G10 (Upstate Biotechnology Inc., NY, USA). The membranes were reprobed with ab7522 antibody for total Dab1 detection (Abcam, Cambridge, MA, USA) [49, 50].

\section{Quantitative Real-Time Polymerase Chain Reaction}

Quantitative real-time PCR was performed on total RNA extracted with mirVana's isolation kit (Ambion, Austin, TX, USA) from the cortex of CJD patients or from $\mathrm{Tg} 340$ mice. Purified RNAs were used to generate the corresponding cDNAs, which served as PCR templates for mRNA quantification. Two different sets of primers were used. First for the $\mathrm{Tg} 340$ mice, quantitative RT-PCR assays were performed in duplicate on cDNA samples obtained from the retrotranscription reaction diluted 1:20 in 384-well optical plates (Kisker Biotech, Steinfurt, GE) using the ABI Prism 7900 HT Sequence Detection System (Applied Biosystems). The reactions were carried out using $20 \times$ TaqMan gene expression assays for genes and $2 \times$ TaqMan Universal PCR Master Mix 
(Applied Biosystems). The reactions were conducted using the following parameters: $50{ }^{\circ} \mathrm{C}$ for $2 \mathrm{~min}, 95{ }^{\circ} \mathrm{C}$ for $10 \mathrm{~min}, 40$ cycles at $95{ }^{\circ} \mathrm{C}$ for $15 \mathrm{~s}$ and $60{ }^{\circ} \mathrm{C}$ for 1 min. The fold change was determined using the Eq. $2^{-\Delta \Delta C T}$. Similar results were obtained using two different housekeeping genes for normalization (HPRT and GUSB). The assay numbers of RT-qPCR analysis were Mm00465200 m1 and Mm00465231 m1 for Reelin, Mm00446968_m1 for HPRT, and Mn00446958_g1 for the GUSB housekeeping genes.

For the human CJD samples, PCR amplification and detection were performed with the ROCHE LightCycler 480 detector, using $2 \times$ SYBR GREEN Master Mix (Roche) as reagent, following the manufacturer's instructions. The reaction profile was denaturation-activation cycle $\left(95{ }^{\circ} \mathrm{C}\right.$ for $\left.10 \mathrm{~min}\right)$ followed by 40 cycles of denaturation-annealing-extension $\left(95^{\circ} \mathrm{C}\right.$ for $10 \mathrm{~min}, 72^{\circ} \mathrm{C}$ for $1 \mathrm{~min}, 98^{\circ} \mathrm{C}$ continuous). mRNA levels were calculated using the LightCycler 480 software. Data were analyzed with SDS 1.9.1 software (Applied Biosystems) following the $2^{-\Delta \Delta C T}$ method of Applied Biosystems. Primers were as follows: Reln (5'-actctgtcaacagctcaagc-3') and (5'tggtcaattgcccagctttg- $\left.3^{\prime}\right)$. The results were normalized for the expression levels of the housekeeping gene, gapdh (5'aggtcggtgtgaacggatttg-3') and (5'-tgtagaccatgtagttgaggtca-3'), which were quantified simultaneously with the target gene [58].

\section{Immunohistochemistry and In Situ Hybridization}

In situ hybridization was carried out as described previously [59] on 40- $\mu \mathrm{m}$ frozen adult brain sections. Both sense and antisense riboprobes were labeled with digoxigenin according to the manufacturer's instructions (Roche Farma). For the immunohistochemistry studies of frozen brain sections, tissue was incubated with primary antibodies overnight, followed by appropriate secondary antibodies. Tissue binding primary antibody was detected using the $\mathrm{ABC}$ method. Briefly, free-floating sections were rinsed in $0.1 \mathrm{M}$ PBS, and endogenous peroxidase activity was blocked by incubation in $3 \%$ $\mathrm{H}_{2} \mathrm{O}_{2}$ and $10 \%$ methanol dissolved in $0.1 \mathrm{M}$ PBS. After extensive rinsing, sections were incubated in 0.1 M PBS containing $0.2 \%$ gelatin, $10 \%$ normal goat serum, $0.2 \%$ glycine, and $0.2 \%$ Triton-X 100 for $1 \mathrm{~h}$ at room temperature. Afterward, sections were incubated for $24 \mathrm{~h}$ at $4{ }^{\circ} \mathrm{C}$ with the primary antibody: $\alpha$-calbindin and $\alpha$-parvalbumin (1:2000 diluted; Swant Antibodies, Switzerland). After that, sections were incubated with secondary biotinylated antibodies ( $2 \mathrm{~h}, 1: 200$ diluted) and streptavidin-horseradish peroxidase complex $(2 \mathrm{~h}$, 1:400 diluted). Peroxidase activity was revealed with $0.025 \%$ diaminobenzidine (DAB) and $0.003 \%$ hydrogen peroxide. After rinsing, sections were mounted onto slides, dehydrated, and cover-slipped with Eukitt ${ }^{\mathrm{TM}}$ (Merck). Samples were photo-documented using an Olympus BX61 microscope equipped with a cooled digital DP72L camera. For cell counting, the radial distribution of Reln-, calbindin-, or parvalbumin-positive cells was analyzed. Positive cells in individual layers were counted with a $\times 20$ objective in $500-\mu \mathrm{m}$ thick vertical strips covering the entire radial extent of the neocortex.
Fig. 1 a, b Example of western blot determination of reelin in $\operatorname{Prnp}^{+/ 4}, \operatorname{Prnp}^{0 / 0}$, and Tga20. The quantification of the obtained results is plotted in $\mathbf{b}$. Each $d o t$ corresponds to one experiment. c-e Low power

photomicrographs illustrating the distribution of Reln mRNA in the cerebral cortex of 3-month-old $\operatorname{Prnp}^{0 / 0}$ (c) and $\operatorname{Prnp}^{+/+}$(d). e Radial distribution of Relnpositive neurons in $\operatorname{Prnp}^{0 / 0}$ and Prnp $^{+/+}$adult mice. Cortical layers are indicated on the $\mathrm{Y}$ axis. Bars represent the mean \pm S.E.M. of the total number of cells counted in eight consecutive sections of four adult mice per genotype. No statistical differences in the numbers of Reln-positive cells were seen between genotypes
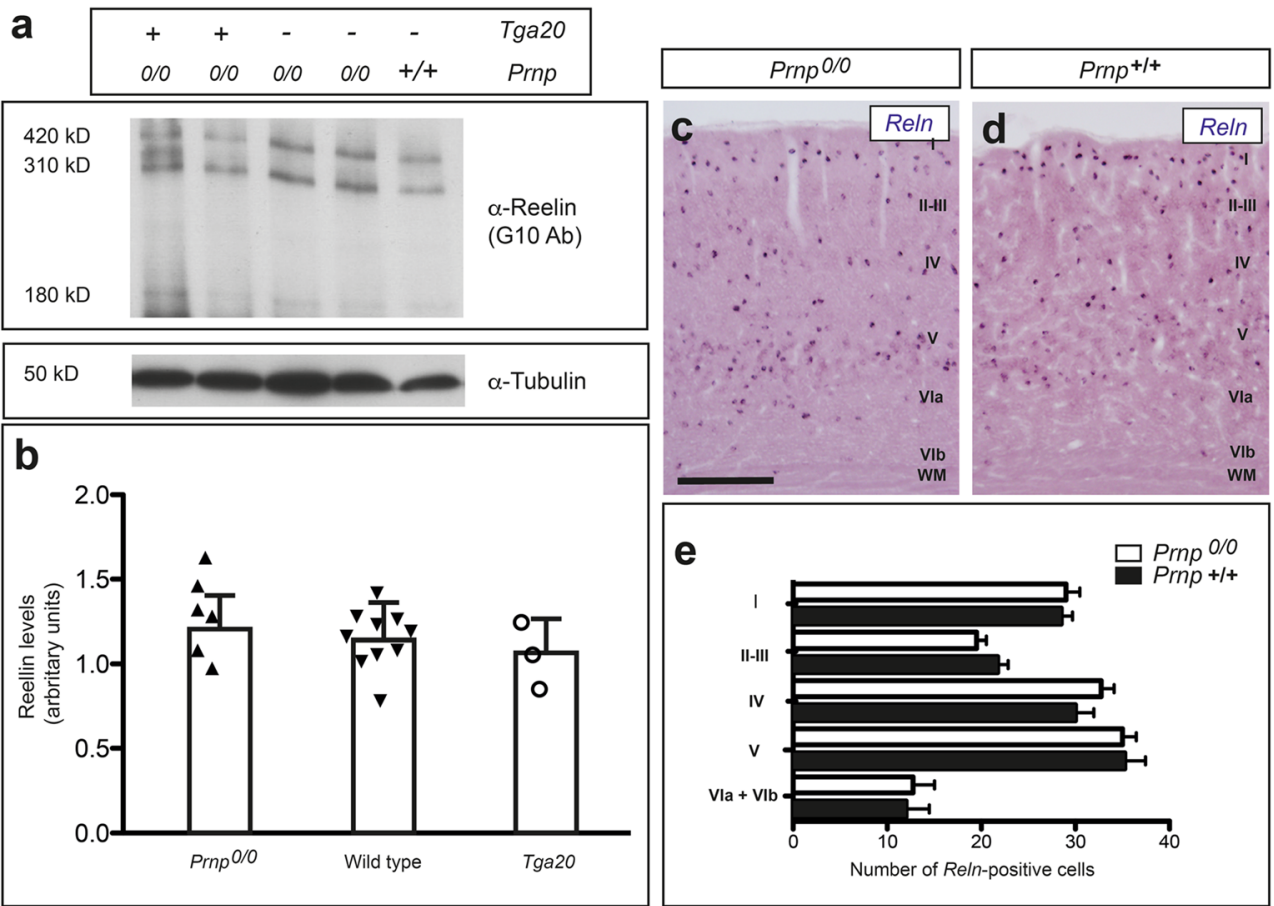


\section{Densitometry and Statistical Processing}

For quantification, developed films were scanned at $2400 \times 2400$ dpi (i800 MICROTEK high-quality film scanner), and the densitometric analysis was performed using Quantity One Image software analysis (Biorad, Windows) and the Gel-Pro analyzer (Media Cybernetics, Windows). Statistical analysis of the obtained data was performed using Bonferroni post hoc test (Multiple comparison test) using GraphPad Prism 5.0c (Mac OsX, Grahpad). Data are presented as mean \pm standard error of the mean (S.E.M.). Differences between groups were considered statistically significant at $* P<0.05$.

\section{Results}

\section{Adult Cortical Levels of Reelin Are Not Modified by Changes in Prnp Dosage}

Endogenous levels of Prnp are reduced around $50 \%$ in CJD patients [60]. This differs from what is reported in infected mice [61]. Therefore, we aimed to determine putative changes in the presence of Reelin in CJD patients and infection models and to determine whether Prnp expression levels correlated with changes in Reelin protein levels (Fig. 1). Cortical brain extracts from Prnp ${ }^{o / o}$, Prnp $^{+/+}$, and Tga20 mice were processed for reelin detection with western blotting (Fig. 1a, b).
Fig. 2 a Time course of Reelin, ApoeR2, and VLDL expressions in cortical cultures exposed to $80 \mu \mathrm{M}$ aggregated $\operatorname{PrP}(106-126)$ for $24 \mathrm{~h}$ and 4 days. Tubulin and actin were used as control loading protein. $\mathbf{b}$ Graph of the densitometric values of ApoeR2 and VLDLR levels in the experiment. Plots show mean \pm S.E.M. of five different experiments. c Dab1

phosphorylation in the presence of $\operatorname{PrP}_{(106-126)}$ in reeler-derived neurons. The quantification of experiments is shown in $\mathbf{d}$. Plots show mean \pm S.E.M. of two different experiments. $* P<0.05$, ANOVA Bonferroni post hoc test. e Graph of the percentage of the PI fluorescence measures of PrP(106-126) treated cultures. Plots show mean \pm S.E.M. of three different experiments. $\mathbf{f}$ Western blot determination of reelin protein levels in primary neuronal cultures after $\operatorname{PrP}_{(106-}$ 126) treatment. Cultures were treated with $80 \mu \mathrm{M} \operatorname{PrP}_{(106-126)}$ peptide for one in absence or presence of NAC and DPI (see the "Material and Methods" section for details). Tubulin was used as control loading protein
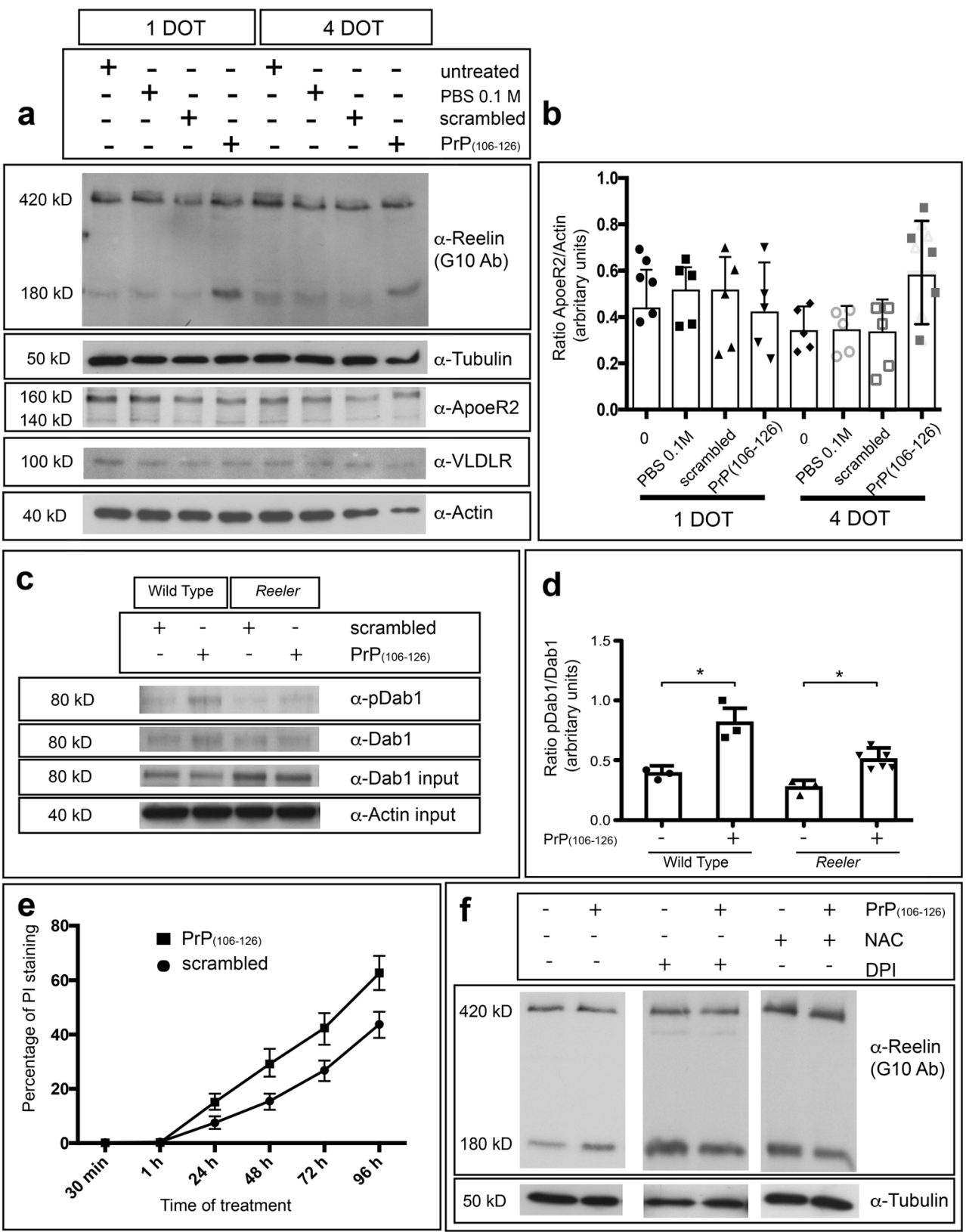
Results indicated no statistically significant differences in Reelin content between genotypes although Prnp $^{o / o}$ showed a $\sim 6 \%$ increase compared to wild type $((1.204 \pm 0.19$ $\left(\operatorname{Prnp}^{o / o}\right)$ vs $1.128 \pm 0.055\left(\right.$ Prnp $\left.^{+/+}\right)$vs $1.065 \pm 0.215$ (Tga20); mean \pm S.E.M.) (Fig. 1b). Next, we aimed to corroborate these results by analyzing Reln mRNA expression in the neocortex of $\operatorname{Prnp}^{0 / 0}$ and $\mathrm{Prnp}^{+/+}$with in situ hybridization (Fig. 1c-e). Qualitative (Fig. 1c, d) and quantitative (Fig. 1e) data corroborated that there were no relevant differences in the Reln mRNA expression between the two genotypes.

\section{Increased Reelin Expression in $\operatorname{PrP}_{(106-126)}$-Treated Primary Cortical Neurons Does Not Correlate with Activation of the Reelin Pathway}

Peptides mimicking prion sequences (e.g., human or mouse) have been used as models of prion-mediated cytotoxicity for many years [62-65]. Thus, we aimed to check the effects of $\operatorname{PrP}_{(106-126)}$ in modifying Reelin protein levels in primary cortical neurons (Figs. 2 and 3). First, to avoid the effects associated with low endogenous expression of $\mathrm{PrP}^{\mathrm{C}}$ levels, these were determined in primary cortical cultures at several days in vitro (DIV) in order to establish the appropriate time window for treatments (Supplementary Fig. 1). Reasonable levels of $\operatorname{PrP}^{\mathrm{C}}$ in cultures were detected after 12-15 days in vitro (Supplementary Fig. 1). In a second set of experiments, cortical neurons were maintained in vitro for 15 DIV and incubated with $80 \mu \mathrm{M}$ aggregated $\operatorname{PrP}_{(106-126)}$ [66] for $30 \mathrm{~min}, 1$ day, and 4 days, and Reelin expression levels were analyzed (Figs. 2a and 3). Parallel cultures were incubated with scrambled peptide, 0.1 M PBS, untreated as internal controls (Fig. 2a). In addition, levels of Dab1 phosphorylation were also checked after $\operatorname{PrP}_{(106-126)}$ treatment (Fig. 3). Results indicate that in the treated cultures, the upper band of $420 \mathrm{kD}$

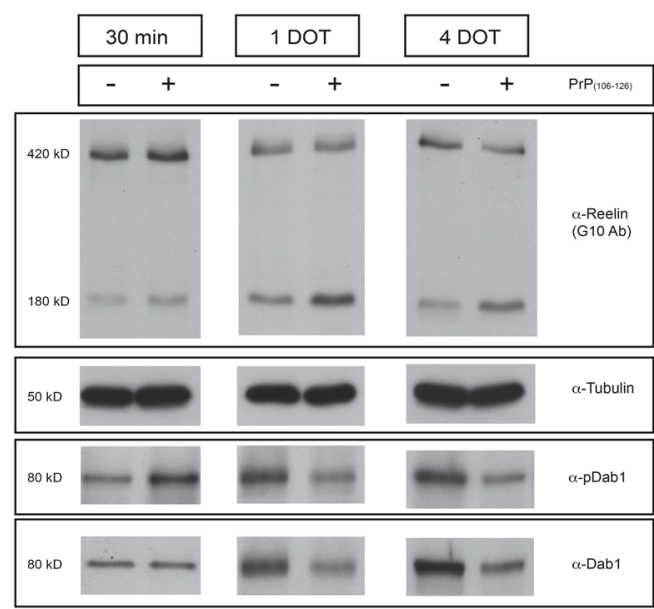

Fig. 3 a Parallel determination of reelin, p-Dab1, and Dab1 levels in primary neuronal cultures after $\operatorname{PrP}_{(106-126)}$ treatment. Cultures were treated with $80 \mu \mathrm{M} \operatorname{PrP}_{(106-126)}$ peptide for the times indicated (30 min, 1 day, and 3 days). Reelin-probed membranes were immunoblotted using antibodies against tubulin for standardization. The phosphorylated form and the lower band of $180 \mathrm{kD}$ of cellular Reelin could be easily distinguished in protein extracts (Fig. 2a and 3). In addition, they showed a 1.25 -fold increase in total Reelin at $24 \mathrm{~h}$ after $\operatorname{PrP}_{(106-126)}$ treatment $(P<0.05, t=2.819,95 \%$ confidence interval of diff. $=-08.699$ to $0.04990(1$ vs 1 day + $\operatorname{PrP}(106-126))$ ); ANOVA Bonferroni post hoc test (Fig. 3). This Reelin increase can be seen, albeit reduced, 4 days after treatment (1.21-fold increase) $(P<0.05, t=3249,95 \%$ confidence interval of diff. $=-0.7222$ to -0.009744 (4 vs 4 day $+\operatorname{PrP}_{(106-}$ 126) ANOVA Bonferroni post hoc test) (Fig. 3). Surprisingly, this increase in Reelin is delayed with respect to the increase in p-Dab1 and degradation (Fig. 3). Indeed, increased p-Dab1 was observed shortly after $30 \mathrm{~min}$ of incubation with $\operatorname{PrP}_{(106-126)}$ (Fig. 3). This happens prior to the Reelin increase (24 h) suggesting that early Dab1 phosphorylation is not mediated by Reelin (Fig. 3). In addition, this data suggests that these changes in Reelin do not correlate with increased Reelin-mediated signaling. This was also corroborated by analyzing ApoER2 levels [67]. Changes in ApoER2 levels are modulated by Reelin signaling [67]. However, ApoeR2 and VLDLR levels remained constant during these periods, except after 4 days in vitro, they were slightly changed without reaching statistical signification (Fig. 2b). Quantification of ApoeR2/Actin ratio was $0.62 \pm 0.02$ (untreated) vs $0.41 \pm 0.09\left(\mathrm{PrP}_{(106-126)}\right) 1$ day of treatment (mean \pm S.E.M.) and $0.34 \pm 0,03$ (untreated) vs $0.59 \pm 0.09$ $(\operatorname{PrP}(106-126)) 4$ days of treatment (mean \pm S.E.M.). Quantification of VLDLR/Actin ratio was $0.69 \pm 0.06$ (untreated) vs $0.49 \pm 0.091$ day of treatment (mean \pm S.E.M.) and $0.53 \pm 0.06$ (untreated) vs $0.70 \pm 0,10$; 4 days of treatment (mean \pm S.E.M.). Changes after 4 days might reflect changes in cell death due to the amyloid treatment. In fact, a higher level of cell death was monitored by using propidium iodide uptake in $\operatorname{PrP} P_{(106-126)}$-treated cultures

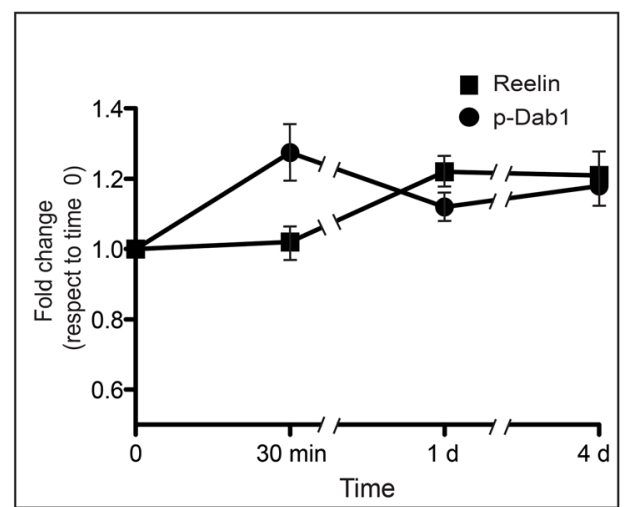

of Dab1 was analyzed by immunoprecipitation and western blotting. Membranes were re-probed with an antibody against total Dab1. b Graph of the densitometric values of reelin and p-Dab1 levels. Plots show mean \pm S.E.M. of three different experiments 
compared to controls (PI staining $=62.65 \pm 5.16, \operatorname{PrP}_{(106-126)}$ vs $43.77 \pm 3.23$, scrambled, at $96 \mathrm{~h}$ of treatment) (Fig. 2e). Next, in order to determine whether the fast Dab1 phosphorylation observed after peptide treatment is related with Reelin, we processed primary neuronal cultures obtained from reeler mice. Treatment of reeler-derived cortical neurons lacking reelin with $\operatorname{PrP}_{(106-126)}$ is also able to increase $\mathrm{p}$-Dab1 $\left(0.293 \pm 0.0159\right.$ (scrambled) vs $0.498 \pm 0.033\left(\operatorname{PrP}_{(106-126)}\right)$, mean \pm S.E.M., $P<0.05, t=3.381,95 \%$ confidence interval of diff. $=-0.398$ to -0.010 ; ANOVA Bonferroni post hoc test) (Fig. 2c, d), reinforcing the notion that the presence of reelin is not mandatory in the increased $\mathrm{p}$-Dab1 levels mediated by $\operatorname{PrP} P_{(106-126)}$. Increased kinase activity and high levels of ROS have been described after prion infection [33, 66, 68-70] and in sCJD patients [33]. Thus, we aimed to explore whether ROS generation in treated cultures participates in the observed changes in Reelin expression. Results showed that the ROS scavenger NAC and the NADPH oxidase inhibitor DPI are able to block Reelin increase mediated by $\operatorname{PrP}_{(106-126)}$ (Fig. 2f).

\section{Decreased Reelin Protein Levels in Prion-Inoculated Mice}

Prnp $^{+/+}$were inoculated with $22 \mathrm{~L}$ or Mo-BSE prions, and cortical levels of Reelin were determined in cortical extracts of terminal mice (137-138 days (22L) and 201-202 days (Mo-BSE)). Developed film demonstrated a decrease in Reelin levels in 22L-inoculated mice $(0.5360 \pm 0.028$ (noninoculated) vs $0.2990 \pm 0.055$ (22L inoculated), mean \pm S.E.M., $P<0.05, t=4.943 ; 95 \%$ confidence interval of diff. $=0.1188$ to 0.4091 ; ANOVA Bonferroni post hoc test) (Fig. 4). Mo-BSE-inoculated mice also showed reduced Reelin content compared to non-inoculated mice $(0.3510 \pm 0.026$ (Mo-BSE inoculated), mean \pm S.E.M., $P<0.05, t=3.602 ; 95 \%$ confidence interval of diff. $=0.0525$ to 0.3755 (Fig. 4). This decrease in Reelin could be due to a decrease in Reelin-expressing cells in affected brains. Thus, terminal prion-inoculated mice $\left(\right.$ Prnp $\left.^{+/+}\right)$and time-matched $\operatorname{Prnp}^{0 / 0}$ inoculated mice were histologically processed to Reln with in situ hybridization (Fig. 5). Cell counts of revealed sections demonstrated that neither the distribution nor the total number of Reln-positive cells was significantly modified in the neo cortex of the inoculated mice compared with the controls (Fig. 5). As Reelin is expressed mainly by cortical interneurons in adult cortex (mainly in calbindin, calretinin, NPY-, and somatostatin- but rarely on parvalbumin-, cholecystokinin-, or VIP-positive interneurons) [71], we also analyzed the number of calbindin- and parvalbumin-positive interneurons in the neocortex of inoculated and control mice. Results showed similar numbers of calbindin-positive cells in inoculated and non-inoculated mice (Fig. 5b-h). In contrast, the number of parvalbumin-positive cells decreased slightly $(\approx 16.3 \%)$ in layers IV-VI of $\operatorname{Prnp}^{+/+}$-inoculated mice

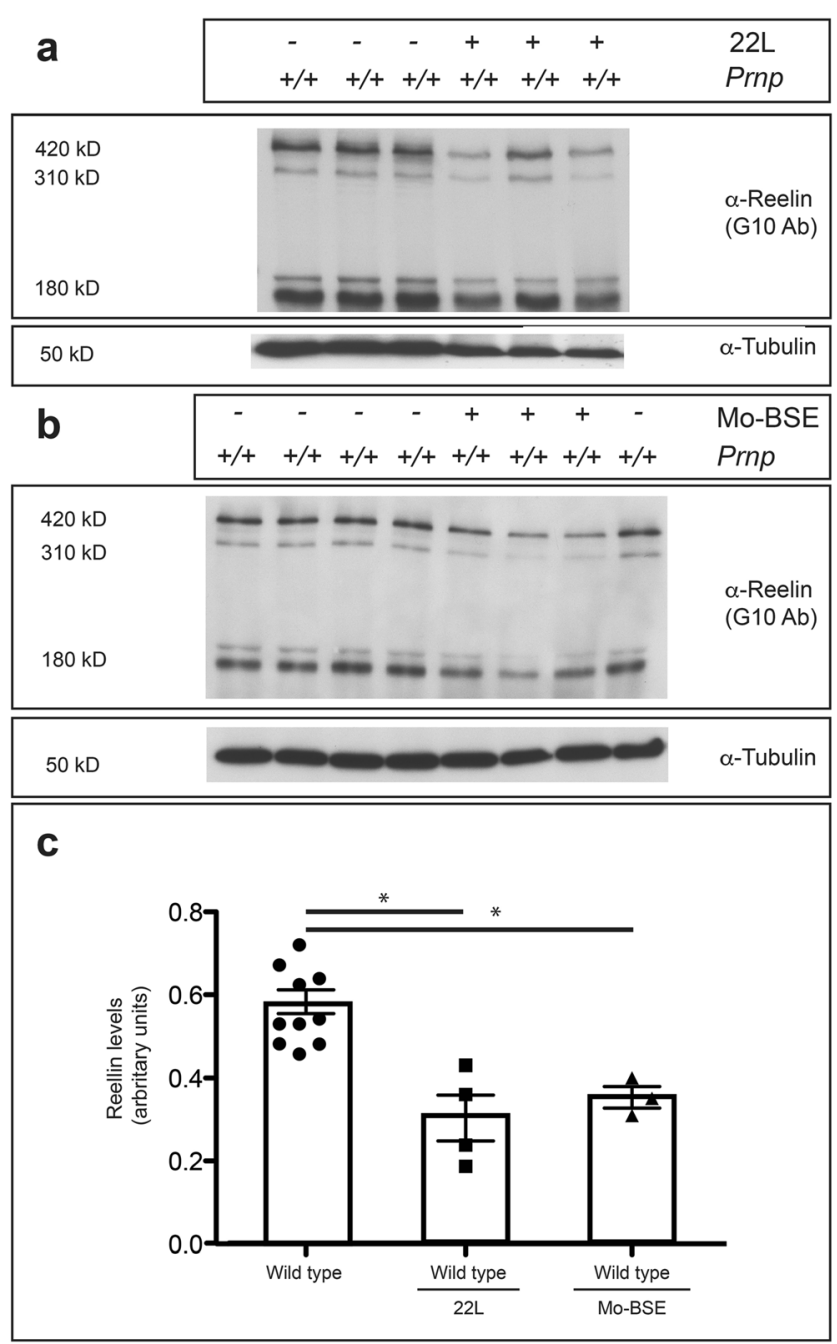

Fig. 4 Example of western blotting determination of Reelin in 22L (a) or Mo-BSE (b)-inoculated mice. c Histograms showing the densitometric study. Plots show mean \pm S.E.M. of each different type of mouse. Each dot corresponds to one mouse. Asterisks indicate statistical differences between groups. $* P<0.05$; ANOVA Bonferroni post hoc test

(Fig. 5c-i) corroborating previous results [72]. Taken together, these results indicate that a direct effect of changes in Reelin protein levels on non-pyramidal neuron populations in inoculated mice is unlikely.

\section{Changes in Reelin Expression in CJD Post-Mortem Samples and CJD-Inoculated Mice}

Total levels of Reelin and Reln mRNA changes were analyzed in human post-mortem samples of frontal cortex of CJD patients (Tables 1 and 2; Fig. 6). Although the data did not reach a $P$ value $<0.05$ (Type II vs control; $t=0,6165 ; 95 \%$ confidence interval of diff. $=-0.312$ to 0.421 ; ANOVA Bonferroni post hoc test), the results indicated a tendency of higher level of Reelin in CJD patients, especially in type II (5.450 \pm 0.490 (type II) vs $4.973 \pm 0.490$ (type I) vs $4.203 \pm 0.4214$ (control)) (Fig. 6b). This tendency in CJD patients was also corroborated 
Fig. 5 a-f Low power photomicrograph illustrating the distribution of Reel- $(\mathbf{a}, \mathbf{d})$, calbindin- (CALB) (b, e), and parvalbumin (PARV) $(\mathbf{c}, \mathbf{f})$ positive neurons in the neocortex of inoculated $\mathrm{Prnp}^{+/+}$and Prnp ${ }^{0 / 0}$ mice. $\mathbf{g}-\mathbf{i}$ Radial distribution of Reln- (g), calbindin- (S.E.M.), and parvalbumin (i)-positive neurons in rrnp $^{0 / 0}$ and Prnp ${ }^{+/ 4}$ adult inoculated mice. Calbindinpositive cells were ascertained as interneurons for quantification. Cortical layers are indicated in the S.E.M. axis. Layer VIa + VIb were grouped. Bars represent the mean \pm S.E.M. of the total number of cells counted in eight consecutive sections of two $\left(\right.$ Prnp $\left.^{+/+}\right)$and seven $\left(\right.$Prnp $\left.^{0 / 0}\right)$ mice. No statistical differences in the numbers of positive cells were seen between genotypes, except for parvalbumin-positive cells located in layers IV-VI)
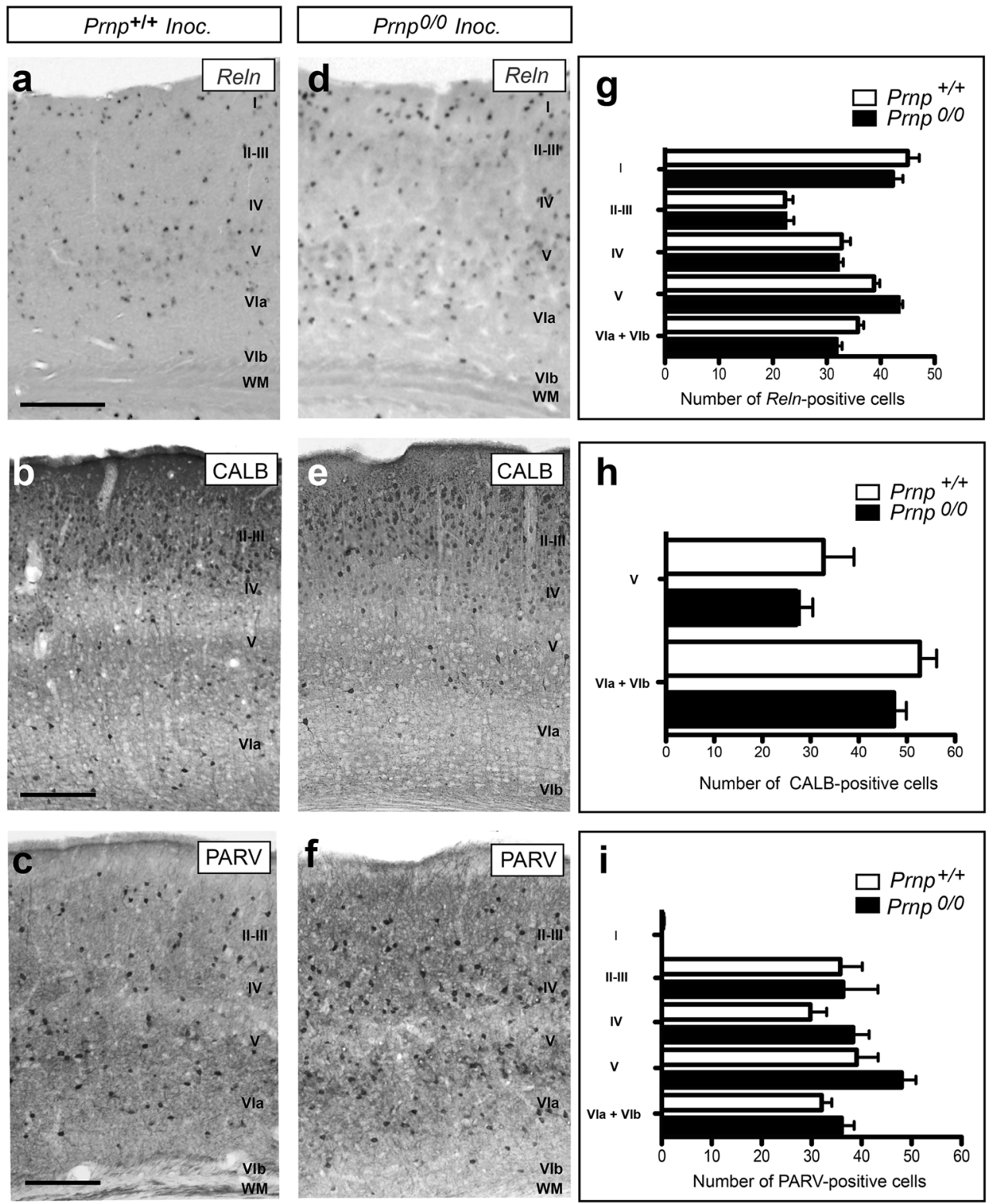

by RT-qPCR ( $1.693 \pm 0.382$ (type II) vs $1.703 \pm 0.5125$ (type I) vs $1.090 \pm 0.2050$ (control)) (Fig. 6c). In parallel, we also aimed to determine mRNA levels of Reln in the cerebral cortices of Tg340 mice inoculated with human Met/Met PrP type 1 inoculum (Fig. 6d). Tg340 mice inoculated with sCJD showed a faster evolution of the infective process (around 180 days post-inoculum (DPi)) than 22L in Mo-BSE infected mice). In addition, they showed increased levels of Reln mRNA at these days post-inoculation (Fig. 6d) $(0.1245 \pm 0.013$ (Con) vs $0.2210 \pm 0.026$ (CJD); mean \pm S.E.M., $1.71 \pm 0.23$-fold increase; $P=0.0141$; $t=3.248 ; 95 \%$ confidence interval of diff. $=-0.79$ to $0.244)$. In previous $\mathrm{DPi}$, asymptomatic mice (120 DPi) or those with few symptoms (160 DPi), levels of Reelin were identical to control mice (Fig. 6d). Unfortunately, processing of paraffin-embedded $\operatorname{Tg} 340$ mice or post-mortem (CJD) human samples with formic acid impairs the use of current antibodies against Reelin or Reln mRNA detection to expand these biochemical data histologically.

\section{Discussion}

The glycoprotein Reelin plays relevant roles during development, maturation, and adult synapse maintenance of the nervous system. In addition, it plays a neuroprotective role in Alzheimer's disease against $\beta$-amyloid-associated cytotoxicity $[12,47]$. Unfortunately, its presence in brain parenchyma decreases during normal development, aging, and neurodegeneration [36, 41, 42]. In addition, in Alzheimer's disease, 
Table 2 Main clinical characteristics of SCJD and control cases in the qRT-PCR study

\begin{tabular}{lllll}
\hline Case number & Gender & Age & Codon 129 & PrP type \\
\hline CJD1 & $F$ & 72 & MM & 1 \\
CJD2 & $M$ & 46 & MM & 1 \\
CJD3 & $M$ & 64 & MM & 1 \\
CJD4 & $M$ & 66 & MM & 1 \\
CJD5 & $M$ & 70 & MM & 1 \\
CJD6 & $M$ & 66 & VV & 2 \\
CJD7 & $F$ & 76 & VV & 2 \\
CJD8 & $M$ & 65 & VV & 2 \\
CJD9 & $F$ & 47 & VV & 2 \\
CJD10 & $M$ & 54 & VV & 2 \\
Control1 & $M$ & 85 & & \\
Control2 & $M$ & 62 & & \\
Control3 & $M$ & 59 & & \\
Control4 & $M$ & 39 & & \\
Control5 & $M$ & 78 & & \\
\hline
\end{tabular}

$F$ female, $M$ male, $M M$ methionine, $V$ :valine, $\operatorname{Pr} P^{s c}$ type 1 lower band of glycosylated $\operatorname{PrP}^{\mathrm{sc}}$ of $21 \mathrm{kD}$, type 2 lower band of glycosylated $\operatorname{PrP}^{\mathrm{sc}}$ of $10 \mathrm{kD}$

Reelin seems not to be functional when generated in the presence of $\beta$-amyloid [46, 73]. Thus, Reelin-dependent induction of Dab1 phosphorylation appeared reduced in the presence of $\beta$-amyloid being unable to modulate the cleavage of ApoER2 [46].These functional changes in Reelin are likely associated to changes in Reelin glycosylation [37]. These changes compromise its capacity to bind to ApoER2, impeding the ability to decrease tau phosphorylation [46, 73]. A reduced Reelin expression is associated with impaired signaling, resulting in cognitive decline [24, 74]. Blockage of reelin signaling is sufficient to impair memory [75]. Thus, impaired Reelin signaling could contribute to the clinical symptoms and pathological progression in neurodegeneration.

Although Reelin expression levels have been characterized in some neural diseases (see the "Introduction" section for references), no data have been published on natural TSEs or on models of prion infection. Bearing this in mind, we sought to determine whether Reelin levels changed in TSEs and to check their putative changes as a putative diagnostic biomarker of prion diseases. First, we determined that levels of Reelin were not modified with different doses of Prnp. This contrasts with a decrease in Reelin in brain extracts of $\operatorname{Prnp}^{0 / 0}$ mice reported by Devanathan and co-workers [76]. This difference could be associated with the use of Zürich I Prnp ${ }^{0 / 0}$ mice [76] in contrast to C57B16/J backcrossed B6.129 mice with lower 129Sv loci (our study; see also [77, 78] for details). In fact, we determined that adult Reln mRNA levels were not modified between $\operatorname{Prnp}^{0 / 0}, \operatorname{Prnp}^{+/+}$, and Tga20 mice in a previous study [77] as also observed by [79].
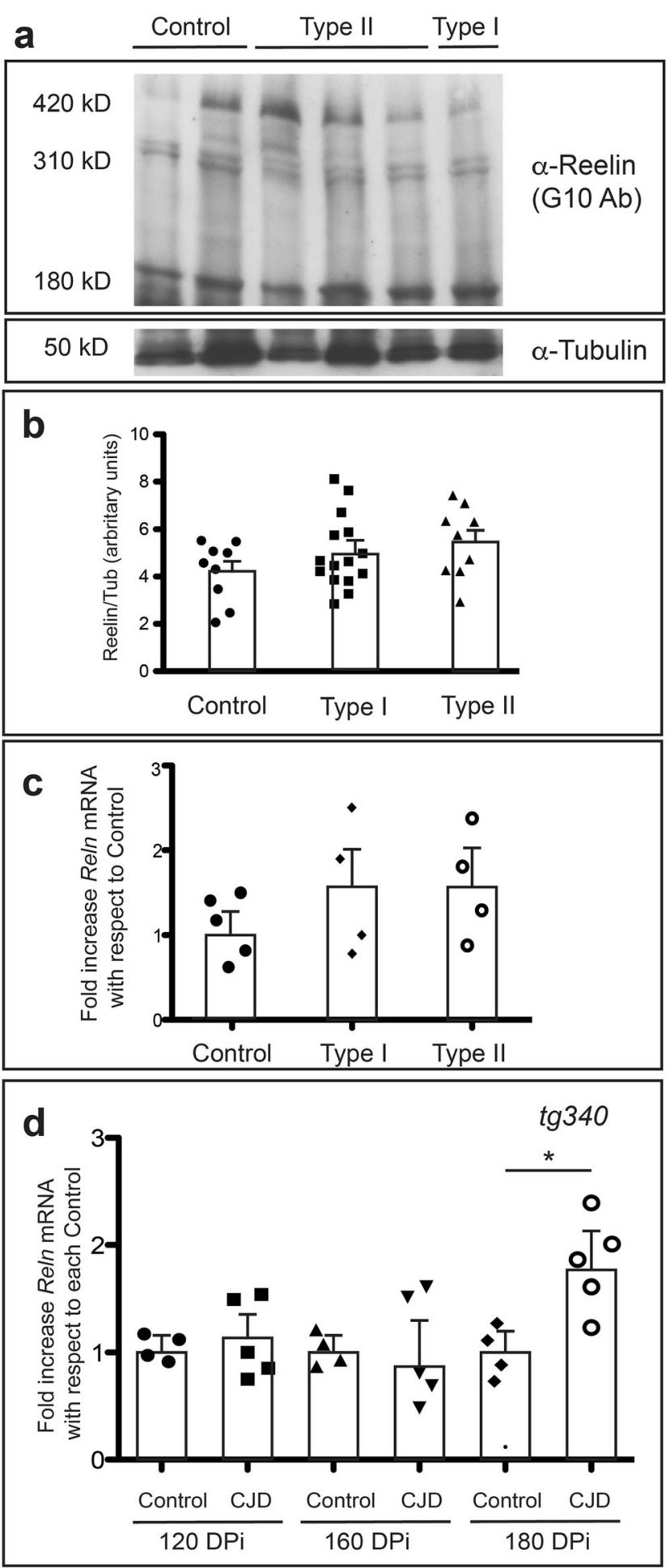

Fig. 6 Examples of western blotting determination of Reelin $(\mathbf{a}, \mathbf{b})$ and Reln mRNA quantification by RT-qPCR (c) in SCJD cases compared to controls. However, no statistically significant increased levels of Reelin or Reln mRNA can be seen in the sCJD group (types I and II) compared to controls. d Histograms showing results of Reln mRNA levels (mean \pm S.E.M.) in the cortex of Tg340 mice at 120, 160, and 180 DPI. Each dot corresponds to one mouse. Asterisks indicate statistical differences between groups and controls. $* P<0.05$; ANOVA Bonferroni post hoc test 
Our results indicate that Reelin increased in primary cultures when treated with $80 \mu \mathrm{M}$ aggregated peptides mimicking human $\mathrm{PrP}^{\mathrm{C}}$, in post-mortem cortical samples of CJD patients and in the neocortex of infected mice with SCJD type I inoculum. In contrast, mice inoculated with 22L and Mo-BSE prions showed decreased Reelin levels. In this respect, although a clear explanation is not yet available, differences between mouse prion diseases (22L and Mo-BSE) and SCJD in both human and $\mathrm{Tg} 340$ mice could be related to prion strain properties. In fact, similar differences between mice and human TSEs have also recently been reported for Tau content and its phosphorylated form [80]. On the other hand, a recent study reported that Tau, and more specifically p-Tau levels, decreased in brain parenchyma of CJD patients [60]. Reelin acting through Dab1 phosphorylation increases Akt-Pi3K activation, decreasing GSK3 $\beta$ activity and levels of $\mathrm{p}$-Tau $[18,19]$. Thus, it is reasonable to consider that increased levels of Reelin (if functional) in CJD patients (type I and II of PrP) may contribute to maintaining or decreasing levels of $\mathrm{p}$-Tau.

With respect to the in vitro data, we were surprised by the increase in Reelin after peptide treatment, and so we checked previous reported data using similar cultures. It is well known that primary cultures treated with $80 \mu \mathrm{M} \operatorname{PrP}_{(106-126)}$ show activated Akt [66]. However, Simon et al. reported decreased activity of PI3K and Akt in the cerebellum of inoculated mice and neuronal cultures after $\operatorname{PrP}_{(106-126)}(40 \mu \mathrm{M})$ incubation [81, 82], as we found with lower doses of $\operatorname{PrP}_{(106-126)}$ [66]. In our experience, these differences are likely to be associated with the handling, preparation, and concentration of the $\operatorname{PrP}_{(106-126)}$ used for the experiments. High concentrations of $\operatorname{PrP}_{(106-126)}$ increase ROS production in treated cells (Fig. 2) (see also [66, 69, 83]). In this study, we showed that the increase in Reelin after $\operatorname{PrP}_{(106-126)}$ incubation could be linked to a burst of ROS production induced by the peptide. ROS increase runs in parallel to the relevant kinase activation reported after the inoculation of (263 K) [33] or RML $[48,66]$ prions as well as human prion peptides $[66,68]$. In addition, our results also point the need of different approaches (in vivo and in vitro) to analyze prion-derived effects. For example, human-derived peptides are able to induce Dab1 phosphorylation in Reln-derived neurons. Further studies are needed to ascertain the molecular actor/s involved and other kinases are able to increase Dab1 phosphorylation in the absence of reelin as described during development [84].

Due to that mRNA and protein levels in CJD and SCJDinfected mice only occur at the final stages of the disease, we believe that the increased Reelin changes are likely associated with the profound metabolic changes (e.g., cellular stress, inflammation, etc.) strongly present in the last stages of the infective process. In addition, this invites the question of whether the increased Reelin levels observed in CJD and $\operatorname{Tg} 340$ mice also correspond to a "non-functional" protein has indicated in AD. In fact, low Dab1 phosphorylation is observed in SCJD PrP type II in the presence of the highest levels of Reelin observed in the study (see [50] for description) and levels of p-Tau (normally decreased by functional Reelin) were higher in similar SCJD samples [60, 85].

Levels of $\mathrm{p}$-Tau and Tau have been suggested as a potential biomarker in prionopathies such as the 14-3-3 protein [60, 85, 86]. Reln was associated as a susceptible gene in Alzheimer's disease but not in Parkinson's disease [87]. However, increased levels of a Reelin band of $180 \mathrm{kD}$ have been determined in CSF of AD, Parkinson's disease [37], and frontotemporal dementia [38]. In these neurodegenerative diseases, whether it is the case that Reelin participates in the onset of the disease or its alteration is a secondary effect of the neurodegeneration still remains elusive. Thus, with the present results, it is reasonable to consider that observed changes in Reelin at advanced stages of the prionopathies are secondary to the degenerative process and are probably associated with the physiological changes observed in the disease $[88,89]$. In conclusion, Reelin increase is not associated with the processes linked to early onset of disease and is therefore not a potential biomarker for prionopathies.

Acknowledgments The authors thank Tom Yohannan for the editorial advice and M. Segura-Feliu for the technical assistance. We thank members of the Del Río, Torres, Requena, Zerr and Ferrer groups for stimulating discussions and ideas. We thank members of José Luis Labandeira laboratory (CIMUS) for helping us with the histological processing of the inoculated mice. We also thank Eduardo Soriano for the gift of the reeler mice and Tom Curran for the gift of the Reln in situ probe. This research was supported by grants from the Spanish Ministry of Economy and Competitiveness (MINECO) (BFU2015-67777-R and TEC2015-72718EXP), the Spanish prion network (Prionet Spain, AGL2015-71764REDT), the Generalitat de Catalunya (SGR2014-1218), CIBERNED (PI2014/02-4 (Rapid dementias) and PRY-14-114), and La Caixa Obra Social Foundation, La Marató de TV3 to JADR. R.G. was supported by Fondo de Investigaciones Sanitarias (FIS, PI11-00075). I.F. was funded by the Ministerio de Ciencia e Innovación, Instituto de Salud Carlos IIIFondos FEDER, a way to build Europe FIS grants PI14/00757, and CIBERNED (PI2014/02-4). JM.T. was supported by Spanish Ministry Economy and Competitiveness (RTA2012-00004 and AGL2012-37988C04 projects). J.R.R. was supported by a grant from the Spanish Ministry of Economy and Competitiveness (MINECO) (BFU2013-48436-C2-1-P). I.Z. received support by the Robert-Koch-Institute through funds of Federal Ministry of Health (grant no. 1369-341) and DZNE (German Center for Neurodegenerative Diseases). A.M. was supported by a fellowship from the Spanish Ministry of Economy and Competitiveness. S.V was supported by a Juan de la Cierva contract of the Spanish Ministry of Science and Innovation (MICIM).

\section{Compliance with Ethical Standards}

Ethics Statement All experiments were performed under the guidelines and protocols of the Ethical Committee for Animal Experimentation (CEEA) of the University of Barcelona, and the protocol for the use of animals in this study was reviewed and approved by the CEEA of the University of Barcelona (CEEA approval no. 276/16 and 141/15).

Experiments were approved by the Committee on the Ethics of Animal Experiments of the author's institutions (INIA and INRA; and University of Santiago de Compostela, 15005AE/12/FUN01/PAT05/JRR3).

Conflict of interest The authors declare that they have no conflicts of interest. 


\section{References}

1. D'Arcangelo G, Miao GG, Chen SC, Soares HD, Morgan JI, Curran T (1995) A protein related to extracellular matrix proteins deleted in the mouse mutant reeler. Nature 374(6524):719-723. doi:10.1038/374719a0

2. Soriano E, Del Rio JA (2005) The cells of cajal-retzius: still a mystery one century after. Neuron 46(3):389-394. doi:10.1016/j. neuron.2005.04.019

3. Groc L, Choquet D, Stephenson FA, Verrier D, Manzoni OJ, Chavis P (2007) NMDA receptor surface trafficking and synaptic subunit composition are developmentally regulated by the extracellular matrix protein reelin. J Neurosci 27(38):10165-10175. doi:10.1523/ JNEUROSCI.1772-07.2007

4. Rogers JT, Weeber EJ (2008) Reelin and apoE actions on signal transduction, synaptic function and memory formation. Neuron Glia Biol 4(3):259-270. doi:10.1017/S1740925X09990184

5. Ohkubo N, Vitek MP, Morishima A, Suzuki Y, Miki T, Maeda N, Mitsuda N (2007) Reelin signals survival through Src-family kinases that inactivate BAD activity. J Neurochem 103(2):820-830. doi:10.1111/j.1471-4159.2007.04804.x

6. Frotscher M (2010) Role for reelin in stabilizing cortical architecture. Trends Neurosci 33(9):407-414. doi:10.1016/j. tins.2010.06.001

7. Pujadas L, Gruart A, Bosch C, Delgado L, Teixeira CM, Rossi D, de Lecea L, Martinez A et al (2010) Reelin regulates postnatal neurogenesis and enhances spine hypertrophy and long-term potentiation. J Neurosci 30(13):4636-4649. doi:10.1523/ JNEUROSCI.5284-09.2010

8. Beffert U, Weeber EJ, Morfini G, Ko J, Brady ST, Tsai LH, Sweatt JD, Herz J (2004) Reelin and cyclin-dependent kinase 5-dependent signals cooperate in regulating neuronal migration and synaptic transmission. J Neurosci 24(8):1897-1906. doi:10.1523/ JNEUROSCI.4084-03.2004

9. Stary CM, Xu L, Sun X, Ouyang YB, White RE, Leong J, Li J, Xiong X et al (2015) MicroRNA-200c contributes to injury from transient focal cerebral ischemia by targeting reelin. Stroke 46(2): 551-556. doi:10.1161/STROKEAHA.114.007041

10. Won SJ, Kim SH, Xie L, Wang Y, Mao XO, Jin K, Greenberg DA (2006) Reelin-deficient mice show impaired neurogenesis and increased stroke size. Exp Neurol 198(1):250-259. doi:10.1016/j. expneurol.2005.12.008

11. Cuchillo-Ibanez I, Balmaceda V, Botella-Lopez A, Rabano A, Avila J, Saez-Valero J (2013) Beta-amyloid impairs reelin signaling. PLoS One 8(8):e72297. doi:10.1371/journal.pone.0072297

12. Pujadas L, Rossi D, Andres R, Teixeira CM, Serra-Vidal B, Parcerisas A, Maldonado R, Giralt E et al (2014) Reelin delays amyloid-beta fibril formation and rescues cognitive deficits in a model of Alzheimer's disease. Nat Commun 5:3443. doi:10.1038/ ncomms4443

13. Durakoglugil MS, Chen Y, White CL, Kavalali ET, Herz J (2009) Reelin signaling antagonizes beta-amyloid at the synapse. Proc Natl Acad Sci U S A 106(37):15938-15943. doi:10.1073/pnas.0908176106

14. Hiesberger T, Trommsdorff M, Howell BW, Goffinet A, Mumby MC, Cooper JA, Herz J (1999) Direct binding of reelin to VLDL receptor and ApoE receptor 2 induces tyrosine phosphorylation of disabled-1 and modulates tau phosphorylation. Neuron 24(2):481489

15. Trommsdorff M, Gotthardt M, Hiesberger T, Shelton J, Stockinger W, Nimpf J, Hammer RE, Richardson JA et al (1999) Reeler/ disabled-like disruption of neuronal migration in knockout mice lacking the VLDL receptor and ApoE receptor 2. Cell 97(6):689701
16. Bock HH, Herz J (2003) Reelin activates SRC family tyrosine kinases in neurons. Curr Biol 13(1):18-26

17. Herz J, Chen Y (2006) Reelin, lipoprotein receptors and synaptic plasticity. Nat Rev Neurosci 7(11):850-859

18. Beffert U, Morfini G, Bock HH, Reyna H, Brady ST, Herz J (2002) Reelin-mediated signaling locally regulates protein kinase B/Akt and glycogen synthase kinase 3beta. J Biol Chem 277(51):4995849964. doi:10.1074/jbc.M209205200

19. Park TJ, Curran T (2008) Crk and Crk-like play essential overlapping roles downstream of disabled-1 in the reelin pathway. $\mathrm{J}$ Neurosci 28(50):13551-13562. doi:10.1523/JNEUROSCI.432308.2008

20. Ma Y, Wu X, Li X, Fu J, Shen J, Li X, Wang H (2012) Corticosterone regulates the expression of neuropeptide $\mathrm{Y}$ and reelin in MLO-Y4 cells. Mol Cells 33(6):611-616. doi:10.1007/ s10059-012-0053-y

21. Alvarez-Dolado M, Ruiz M, Del Rio JA, Alcantara S, Burgaya F, Sheldon M, Nakajima K, Bernal J et al (1999) Thyroid hormone regulates reelin and dab1 expression during brain development. J Neurosci 19(16):6979-6993

22. Lussier AL, Caruncho HJ, Kalynchuk LE (2009) Repeated exposure to corticosterone, but not restraint, decreases the number of reelin-positive cells in the adult rat hippocampus. Neurosci Lett 460(2):170-174. doi:10.1016/j.neulet.2009.05.050

23. Buret L, van den Buuse M (2014) Corticosterone treatment during adolescence induces down-regulation of reelin and NMDA receptor subunit GLUN2C expression only in male mice: implications for schizophrenia. Int J Neuropsychopharmacol 17(8):1221-1232. doi:10.1017/S1461145714000121

24. Miettinen R, Riedel A, Kalesnykas G, Kettunen HP, Puolivali J, Soininen H, Arendt T (2005) Reelin-immunoreactivity in the hippocampal formation of 9-month-old wildtype mouse: effects of APP/PS1 genotype and ovariectomy. J Chem Neuroanat 30(2-3): 105-118. doi:10.1016/j.jchemneu.2005.06.003

25. Rideau Batista Novais A, Guiramand J, Cohen-Solal C, Crouzin N, de Jesus Ferreira MC, Vignes M, Barbanel G, Cambonie G (2013) $\mathrm{N}$-acetyl-cysteine prevents pyramidal cell disarray and reelinimmunoreactive neuron deficiency in CA3 after prenatal immune challenge in rats. Pediatr Res 73(6):750-755. doi:10.1038/ pr.2013.40

26. Palacios-Garcia I, Lara-Vasquez A, Montiel JF, Diaz-Veliz GF, Sepulveda H, Utreras E, Montecino M, Gonzalez-Billault C et al (2015) Prenatal stress down-regulates reelin expression by methylation of its promoter and induces adult behavioral impairments in rats. PLoS One 10(2):e0117680. doi:10.1371/journal. pone. 0117680

27. Herring A, Donath A, Yarmolenko M, Uslar E, Conzen C, Kanakis D, Bosma C, Worm K et al (2012) Exercise during pregnancy mitigates Alzheimer-like pathology in mouse offspring. FASEB J 26(1):117-128. doi:10.1096/fj.11-193193

28. Cotter D, Pariante CM (2002) Stress and the progression of the developmental hypothesis of schizophrenia. The British Journal of Psychiatry: The Journal of Mental Science 181:363-365

29. Pompili A, Arnone B, Gasbarri A (2012) Estrogens and memory in physiological and neuropathological conditions. Psychoneuroendocrinology 37(9):1379-1396. doi:10.1016/j. psyneuen.2012.01.007

30. Tareen RS, Kamboj MK (2012) Role of endocrine factors in autistic spectrum disorders. Pediatr Clin N Am 59(1):75-88 . doi:10.1016/j. pcl.2011.10.013x

31. Forero DA, Casadesus G, Perry G, Arboleda H (2006) Synaptic dysfunction and oxidative stress in Alzheimer's disease: emerging mechanisms. J Cell Mol Med 10(3):796-805

32. Barron AM, Pike CJ (2012) Sex hormones, aging, and Alzheimer's disease. Front Biosci 4:976-997 
33. Pamplona R, Naudi A, Gavin R, Pastrana MA, Sajnani G, Ilieva EV, Del Rio JA, Portero-Otin M et al (2008) Increased oxidation, glycoxidation, and lipoxidation of brain proteins in prion disease. Free Radic Biol Med 45(8):1159-1166. doi:10.1016/j. freeradbiomed.2008.07.009

34. Fatemi SH, Kroll JL, Stary JM (2001) Altered levels of reelin and its isoforms in schizophrenia and mood disorders. Neuroreport 12(15):3209-3215

35. Fatemi SH, Stary JM, Egan EA (2002) Reduced blood levels of reelin as a vulnerability factor in pathophysiology of autistic disorder. Cell Mol Neurobiol 22(2):139-152

36. Herring A, Donath A, Steiner KM, Widera MP, Hamzehian S, Kanakis D, Kolble K, ElAli A et al (2012) Reelin depletion is an early phenomenon of Alzheimer's pathology. J Alzheimers Dis 30(4):963-979. doi:10.3233/JAD-2012-112069

37. Botella-Lopez A, Burgaya F, Gavin R, Garcia-Ayllon MS, GomezTortosa E, Pena-Casanova J, Urena JM, Del Rio JA et al (2006) Reelin expression and glycosylation patterns are altered in Alzheimer's disease. Proc Natl Acad Sci U S A 103(14):55735578. doi:10.1073/pnas.0601279103

38. Saez-Valero J, Costell M, Sjogren M, Andreasen N, Blennow K, Luque JM (2003) Altered levels of cerebrospinal fluid reelin in frontotemporal dementia and Alzheimer's disease. J Neurosci Res 72(1):132-136. doi:10.1002/jnr.10554

39. Knuesel I, Nyffeler M, Mormede C, Muhia M, Meyer U, Pietropaolo S, Yee BK, Pryce CR et al (2009) Age-related accumulation of reelin in amyloid-like deposits. Neurobiol Aging 30(5): 697-716. doi:10.1016/j.neurobiolaging.2007.08.011

40. Schiffmann SN, Bernier B, Goffinet AM (1997) Reelin mRNA expression during mouse brain development. Eur J Neurosci 9(5): 1055-1071

41. Krstic D, Pfister S, Notter T, Knuesel I (2013) Decisive role of reelin signaling during early stages of Alzheimer's disease. Neuroscience 246:108-116. doi:10.1016/j.neuroscience.2013.04.042

42. Chin J, Massaro CM, Palop JJ, Thwin MT, Yu GQ, Bien-Ly N, Bender A, Mucke L (2007) Reelin depletion in the entorhinal cortex of human amyloid precursor protein transgenic mice and humans with Alzheimer's disease. J Neurosci 27(11):2727-2733. doi:10.1523/JNEUROSCI.3758-06.2007

43. Wirths O, Multhaup G, Czech C, Blanchard V, Tremp G, Pradier L, Beyreuther K, Bayer TA (2001) Reelin in plaques of beta-amyloid precursor protein and presenilin-1 double-transgenic mice. Neurosci Lett 316(3):145-148

44. Doehner J, Madhusudan A, Konietzko U, Fritschy JM, Knuesel I (2010) Co-localization of reelin and proteolytic AbetaPP fragments in hippocampal plaques in aged wild-type mice. J Alzheimers Dis 19(4):1339-1357. doi:10.3233/JAD-2010-1333

45. Kocherhans S, Madhusudan A, Doehner J, Breu KS, Nitsch RM, Fritschy JM, Knuesel I (2010) Reduced reelin expression accelerates amyloid-beta plaque formation and tau pathology in transgenic Alzheimer's disease mice. J Neurosci 30(27):9228-9240. doi:10.1523/JNEUROSCI.0418-10.2010

46. Botella-Lopez A, Cuchillo-Ibanez I, Cotrufo T, Mok SS, Li QX, Barquero MS, Dierssen M, Soriano E et al (2010) Beta-amyloid controls altered reelin expression and processing in Alzheimer's disease. Neurobiol Dis 37(3):682-691. doi:10.1016/j. nbd.2009.12.006

47. Lane-Donovan C, Philips GT, Wasser CR, Durakoglugil MS, Masiulis I, Upadhaya A, Pohlkamp T, Coskun C et al (2015) Reelin protects against amyloid beta toxicity in vivo. Sci Signal 8(384):ra67. doi:10.1126/scisignal.aaa6674

48. Herrmann US, Sonati T, Falsig J, Reimann RR, Dametto P, O'Connor T, Li B, Lau A et al (2015) Prion infections and anti$\mathrm{PrP}$ antibodies trigger converging neurotoxic pathways. PLoS Pathog 11(2):e1004662. doi:10.1371/journal.ppat.1004662
49. Gavin R, Urena J, Rangel A, Pastrana MA, Requena JR, Soriano E, Aguzzi A, Del Rio JA (2008) Fibrillar prion peptide PrP(106-126) treatment induces Dab1 phosphorylation and impairs APP processing and Abeta production in cortical neurons. Neurobiol Dis 30(2): 243-254. doi:10.1016/j.nbd.2008.02.001

50. Gavin R, Ferrer I, del Rio JA (2010) Involvement of Dab1 in APP processing and beta-amyloid deposition in sporadic CreutzfeldtJakob patients. Neurobiol Dis 37(2):324-329. doi:10.1016/j. nbd.2009.10.010

51. Bueler H, Fischer M, Lang Y, Bluethmann H, Lipp HP, DeArmond SJ, Prusiner SB, Aguet M et al (1992) Normal development and behaviour of mice lacking the neuronal cell-surface PrP protein. Nature 356(6370):577-582

52. Fischer M, Rulicke T, Raeber A, Sailer A, Moser M, Oesch B, Brandner S, Aguzzi A et al (1996) Prion protein (PrP) with amino-proximal deletions restoring susceptibility of PrP knockout mice to scrapie. EMBO J 15(6):1255-1264

53. Steele AD, Emsley JG, Ozdinler PH, Lindquist S, Macklis JD (2006) Prion protein $(\mathrm{PrPc})$ positively regulates neural precursor proliferation during developmental and adult mammalian neurogenesis. Proc Natl Acad Sci U S A 103(9):3416-3421. doi:10.1073/pnas.0511290103

54. Ordonez-Gutierrez L, Torres JM, Gavin R, Anton M, ArrobaEspinosa AI, Espinosa JC, Vergara C, Del Rio JA et al (2013) Cellular prion protein modulates beta-amyloid deposition in aged APP/PS1 transgenic mice. Neurobiol Aging 34(12):2793-2804. doi:10.1016/j.neurobiolaging.2013.05.019

55. Cassard H, Torres JM, Lacroux C, Douet JY, Benestad SL, Lantier F, Lugan S, Lantier I et al (2014) Evidence for zoonotic potential of ovine scrapie prions. Nat Commun 5:5821. doi:10.1038/ ncomms 6821

56. Padilla D, Beringue V, Espinosa JC, Andreoletti O, Jaumain E, Reine F, Herzog L, Gutierrez-Adan A et al (2011) Sheep and goat BSE propagate more efficiently than cattle BSE in human PrP transgenic mice. PLoS Pathog 7(3):e1001319. doi:10.1371/ journal.ppat.1001319

57. Vilches S, Vergara C, Nicolas O, Mata A, Del Rio JA, Gavin R (2015) Domain-specific activation of death-associated intracellular signalling cascades by the cellular prion protein in neuroblastoma cells. Mol Neurobiol. doi:10.1007/s12035-015-9360-6

58. Carulla P, Bribian A, Rangel A, Gavin R, Ferrer I, Caelles C, Del Rio JA, Llorens F (2011) Neuroprotective role of PrPC against kainate-induced epileptic seizures and cell death depends on the modulation of JNK3 activation by GluR6/7-PSD-95 binding. Mol Biol Cell 22(17):3041-3054. doi:10.1091/mbc.E11-04-0321

59. Mingorance A, Fontana X, Sole M, Burgaya F, Urena JM, Teng FY, Tang BL, Hunt D et al (2004) Regulation of Nogo and Nogo receptor during the development of the entorhino-hippocampal pathway and after adult hippocampal lesions. Mol Cell Neurosci 26(1):34 49. doi:10.1016/j.mcn.2004.01.001

60. Llorens F, Zafar S, Ansoleaga B, Shafiq M, Blanco R, Carmona M, Grau-Rivera O, Nos C et al (2015) Subtype and regional regulation of prion biomarkers in sporadic Creutzfeldt-Jakob disease. Neuropathol Appl Neurobiol 41(5):631-645. doi:10.1111/ nan. 12175

61. Sandberg MK, Al-Doujaily H, Sharps B, De Oliveira MW, Schmidt C, Richard-Londt A, Lyall S, Linehan JM et al (2014) Prion neuropathology follows the accumulation of alternate prion protein isoforms after infective titre has peaked. Nat Commun 5:4347. doi:10.1038/ncomms5347

62. Forloni G, Angeretti N, Chiesa R, Monzani E, Salmona M, Bugiani O, Tagliavini F (1993) Neurotoxicity of a prion protein fragment. Nature 362(6420):543-546

63. Brown DR (2000) Prion protein peptides: optimal toxicity and peptide blockade of toxicity. Mol Cell Neurosci 15(1):66-78 
64. Vilches S, Vergara C, Nicolas O, Sanclimens G, Merino S, Varon S, Acosta GA, Albericio F et al (2013) Neurotoxicity of prion peptides mimicking the central domain of the cellular prion protein. PLoS One 8(8):e70881. doi:10.1371/journal.pone.0070881

65. Vassallo N (2009) Properties and pathogenicity of prion-derived peptides. Protein Pept Lett 16(3):230-238

66. Gavin R, Braun N, Nicolas O, Parra B, Urena JM, Mingorance A, Soriano E, Torres JM et al (2005) $\operatorname{PrP}(106-126)$ activates neuronal intracellular kinases and Egr1 synthesis through activation of NADPH-oxidase independently of PrPc. FEBS Lett 579(19): 4099-4106. doi:10.1016/j.febslet.2005.06.037

67. Duit S, Mayer H, Blake SM, Schneider WJ, Nimpf J (2010) Differential functions of ApoER2 and very low density lipoprotein receptor in reelin signaling depend on differential sorting of the receptors. J Biol Chem 285(7):4896-4908. doi:10.1074/jbc. M109.025973

68. Schneider B, Mutel V, Pietri M, Ermonval M, Mouillet-Richard S, Kellermann O (2003) NADPH oxidase and extracellular regulated kinases $1 / 2$ are targets of prion protein signaling in neuronal and non neuronal cells. Proc Natl Acad Sci U S A 100(23):1332613331. doi: $10.1073 /$ pnas. 2235648100

69. Pietri M, Caprini A, Mouillet-Richard S, Pradines E, Ermonval M, Grassi J, Kellermann O, Schneider B (2006) Overstimulation of PrPC signaling pathways by prion peptide 106-126 causes oxidative injury of bioaminergic neuronal cells. J Biol Chem 281(38): 28470-28479. doi:10.1074/jbc.M602774200

70. Vilches S, Vergara C, Nicolas O, Mata A, Del Rio JA, Gavin R (2016) Domain-specific activation of death-associated intracellular signalling cascades by the cellular prion protein in neuroblastoma cells. Mol Neurobiol 53(7):4438-4448. doi:10.1007/s12035-0159360-6

71. Alcantara S, Ruiz M, D’Arcangelo G, Ezan F, de Lecea L, Curran T, Sotelo C, Soriano E (1998) Regional and cellular patterns of reelin mRNA expression in the forebrain of the developing and adult mouse. J Neurosci 18(19):7779-7799

72. Guentchev M, Groschup MH, Kordek R, Liberski PP, Budka H (1998) Severe, early and selective loss of a subpopulation of GABAergic inhibitory neurons in experimental transmissible spongiform encephalopathies. Brain Pathol 8(4):615-623

73. Cuchillo-Ibanez I, Balmaceda V, Mata-Balaguer T, Lopez-Font I, Saez-Valero J (2016) Reelin in Alzheimer's disease, increased levels but impaired signaling: when more is less. J Alzheimers Dis. doi:10.3233/JAD-151193

74. Stranahan AM, Haberman RP, Gallagher M (2011) Cognitive decline is associated with reduced reelin expression in the entorhinal cortex of aged rats. Cereb Cortex 21(2):392-400. doi:10.1093/ cercor/bhq106

75. Stranahan AM, Salas-Vega S, Jiam NT, Gallagher M (2011) Interference with reelin signaling in the lateral entorhinal cortex impairs spatial memory. Neurobiol Learn Mem 96(2):150-155. doi:10.1016/j.nlm.2011.03.009

76. Devanathan V, Jakovcevski I, Santuccione A, Li S, Lee HJ, Peles E, Leshchyns'ka I, Sytnyk V et al (2010) Cellular form of prion protein inhibits reelin-mediated shedding of Caspr from the neuronal cell surface to potentiate Caspr-mediated inhibition of neurite outgrowth. J Neurosci 30(27):9292-9305. doi:10.1523/ JNEUROSCI.5657-09.2010

77. Rangel A, Madronal N, Gruart A, Gavin R, Llorens F, Sumoy L, Torres JM, Delgado-Garcia JM et al (2009) Regulation of GABA(a) and glutamate receptor expression, synaptic facilitation and longterm potentiation in the hippocampus of prion mutant mice. PLoS One 4(10):e7592. doi:10.1371/journal.pone.0007592

78. Carulla P, Llorens F, Matamoros-Angles A, Aguilar-Calvo P, Espinosa JC, Gavin R, Ferrer I, Legname G et al (2015) Involvement of $\operatorname{PrP}(\mathrm{C})$ in kainate-induced excitotoxicity in several mouse strains. Sci Rep 5:11971. doi:10.1038/srep11971

79. Benvegnu S, Roncaglia P, Agostini F, Casalone C, Corona C, Gustincich S, Legname G (2011) Developmental influence of the cellular prion protein on the gene expression profile in mouse hippocampus. Physiol Genomics 43(12):711-725. doi:10.1152/ physiolgenomics.00205.2010

80. Rubenstein R, Chang B, Petersen R, Chiu A, Davies P (2015) T-tau and P-tau in brain and blood from natural and experimental prion diseases. PLoS One 10(12):e0143103. doi:10.1371/journal. pone. 0143103

81. Simon D, Herva ME, Benitez MJ, Garrido JJ, Rojo AI, Cuadrado A, Torres JM, Wandosell F (2014) Dysfunction of the PI3K-AktGSK-3 pathway is a common feature in cell culture and in vivo models of prion disease. Neuropathol Appl Neurobiol 40(3):311326. doi:10.1111/nan.12066

82. Newaz K, Sriram K, Bera D (2015) Identification of major signaling pathways in prion disease progression using network analysis. PLoS One 10(12):e0144389. doi:10.1371/journal.pone.0144389

83. Rizzardini M, Chiesa R, Angeretti N, Lucca E, Salmona M, Forloni G, Cantoni L (1997) Prion protein fragment 106-126 differentially induces heme oxygenase- 1 mRNA in cultured neurons and astroglial cells. J Neurochem 68(2):715-720

84. Keshvara L, Magdaleno S, Benhayon D, Curran T (2002) Cyclindependent kinase 5 phosphorylates disabled 1 independently of reelin signaling. J Neurosci 22(12):4869-4877

85. Llorens F, Schmitz M, Karch A, Cramm M, Lange P, Gherib K, Varges D, Schmidt C et al (2015) Comparative analysis of cerebrospinal fluid biomarkers in the differential diagnosis of neurodegenerative dementia. Alzheimers Dement. doi:10.1016/j. jalz.2015.10.009

86. Schmitz M, Ebert E, Stoeck K, Karch A, Collins S, Calero M, Sklaviadis T, Laplanche JL et al (2015) Validation of 14-3-3 protein as a marker in sporadic Creutzfeldt-Jakob disease diagnostic. Mol Neurobiol. doi:10.1007/s12035-015-9167-5

87. Miyashita A, Hatsuta H, Kikuchi M, Nakaya A, Saito Y, Tsukie T, Hara N, Ogishima S et al (2014) Genes associated with the progression of neurofibrillary tangles in Alzheimer's disease. Trans1 Psychiatry 4:e396. doi:10.1038/tp.2014.35

88. Ferrer I (2002) Synaptic pathology and cell death in the cerebellum in Creutzfeldt-Jakob disease. Cerebellum 1(3):213-222. doi:10.1080/14734220260418448

89. Clinton J, Forsyth C, Royston MC, Roberts GW (1993) Synaptic degeneration is the primary neuropathological feature in prion disease: a preliminary study. Neuroreport 4(1):65-68 